NBER WORKING PAPER SERIES

MARRIAGE MARKET EQUILIBRIUM

Robert A. Pollak

Working Paper 22309

http://www.nber.org/papers/w22309

\author{
NATIONAL BUREAU OF ECONOMIC RESEARCH \\ 1050 Massachusetts Avenue \\ Cambridge, MA 02138 \\ June 2016
}

An earlier version of this paper was presented as the Presidential Address at the Society of Labor Economists in Boston in May 2009. Versions of this paper were also presented at the AEA, ESPE, the Milton Friedman Institute Conference on the New Economics of the Family, the MacArthur Network on the Family and the Economy, the University of Chicago, Vanderbilt University, the University of Essex, the University of Michigan, Washington University in St. Louis and the University of Copenhagen. I am grateful to the participants for their comments. I am also grateful to Gary Becker, Jere Behrman, Ted Bergstrom, Bart Hamilton, Karen Norberg, Alvin Roth, Aloysius Siow, Betsey Stevenson, John Weymark, and Justin Wolfers and, especially, to my friend and long-time collaborator Shelly Lundberg for helpful conversations and comments. Neither they nor the workshop participants who made helpful comments bear responsibility for my use of them. The views expressed herein are those of the author and do not necessarily reflect the views of the National Bureau of Economic Research.

NBER working papers are circulated for discussion and comment purposes. They have not been peer-reviewed or been subject to the review by the NBER Board of Directors that accompanies official NBER publications.

(C) 2016 by Robert A. Pollak. All rights reserved. Short sections of text, not to exceed two paragraphs, may be quoted without explicit permission provided that full credit, including () notice, is given to the source. 
Marriage Market Equilibrium

Robert A. Pollak

NBER Working Paper No. 22309

June 2016

JEL No. D1,J12,K36

\begin{abstract}
$\underline{\text { ABSTRACT }}$
The standard Beckerian analysis of marriage market equilibrium assumes that allocation within marriage implements agreements made in the marriage market. This paper investigates marriage market equilibrium when allocation within marriage is determined by bargaining in marriage and compares that model with the standard model. When bargaining in marriage determines allocation within marriage, the marriage market is the first stage of a two-stage game. The second stage, bargaining in marriage, determines allocation within each marriage. This analysis is consistent with any bargaining model with a unique equilibrium as well as with Becker's "altruist model," the model that underlies the Rotten Kid Theorem. Marriage-market participants are assumed to rank prospective spouses on the basis of the allocations they foresee emerging from bargaining in marriage. The first stage game, the marriage market, determines both who marries and, among those who marry, who marries whom (assortative marriage). When bargaining in marriage determines allocation within marriage, the appropriate framework for analyzing marriage market equilibrium is the Gale-Shapley matching model, not the Koopmans-Beckmann assignment model. These models have different implications for who marries, for who marries whom, and for the Pareto efficiency of marriage market equilibrium.
\end{abstract}

Robert A. Pollak

Washington University in St. Louis

Arts and Sciences

and the Olin Business School

Campus Box 1133

1 Brookings Drive

St. Louis, MO 63130-4899

and IZA

and also NBER

pollak@wustl.edu 
May 2016

\title{
Marriage Market Equilibrium
}

\author{
Robert A. Pollak, Washington University in St. Louis and NBER
}

The standard Beckerian analysis of marriage market equilibrium assumes that allocation within marriage implements agreements that the prospective spouses made in the marriage market. That is, prospective spouses make Binding Agreements in the Marriage Market (BAMM) that determine allocation within marriage. I investigate marriage market equilibrium under the alternative assumption that Bargaining In Marriage (BIM) determines allocation within marriage. In addition to the usual focus on who marries whom (i.e., assortative marriage), I emphasize the implications of BAMM and BIM for who marries and who does not, a salient issue in the light of concern about the retreat from marriage. I show that BAMM and BIM can have different implications for who marries and who does not, and, among those who marry, for who marries whom.

When allocation within marriage is determined by BIM, the marriage market is the first stage of a two-stage game that is solved by backwards induction. Bargaining in marriage, the second stage, determines allocation within each marriage. The marriage market, the first stage, determines both who marries and who marries whom. Prospective spouses, when they meet in the marriage market, are assumed to foresee the outcome of BIM. Taking account of the payoffs associated with these outcomes, each man has a ranking of all women and each woman has a ranking of all men. Under these assumptions, BIM implies that the appropriate mathematical framework for analyzing the marriage market is the Gale-Shapley matching model. With additional assumptions, BAMM implies that the appropriate mathematical framework for analyzing the marriage market is the Koopmans-Beckmann assignment model. 
Econometric evidence and casual empiricism support the claim that BIM rather than BAMM determines allocation within marriage. Traditional "unitary" models treated households as economic agents that maximized a household utility function subject to a household budget constraint. Unitary models imply that spouses "pool" their resources. Schultz (1990) and Thomas (1990) were the first to realize that whether control over resources within marriage affects allocation within marriage provides a test of the unitary model against bargaining models of marriage. There is now a wide consensus that control over resources does affect allocation within marriage -- see, for example, Lundberg, Pollak, and Wales (1997), Duflo (2000, 2003), Attanasio and Lechene (2002), and Ward-Batts (2008). For surveys, see Lundberg and Pollak (2008), Duflo (2012) and Doss (2013).

The analysis of marriage market equilibrium with BIM does not depend on the precise specification of the second-stage bargaining game but is consistent with all bargaining models that uniquely determine the payoffs of prospective spouses in every possible marriage. These include Nash bargaining, generalized Nash bargaining, and a wide range of cooperative and noncooperative bargaining models. They also includes Becker's altruist model, the model that underlies the Rotten Kid Theorem, in which one spouse has the power to impose his or her preferred allocation subject to the other's participation constraint. Becker uses the altruist model to analyze allocation within marriage as well as allocation between parents and children. The "nightlight" example, introduced in passing by Becker (1981, 1991 p. 284) and elaborated by Bergstrom (1989) to clarify an important analytical point about the crucial role of transferable utility in the altruist model, has the unfortunate effect of trivializing the model's important insight: in societies in which wives have little or no bargaining power, allocation within marriage will reflect husbands' preferences. ${ }^{1}$ The altruism model has historical and, in some societies, contemporary relevance, but it is not a

\footnotetext{
${ }^{1}$ All page citations to Becker's Treatise on the Family are to the 1991 enlarged edition, although virtually all of the cited material appeared in the 1981 edition and, before that, much of it in journal articles.
} 
plausible model for analyzing allocation within marriage in contemporary Europe or North America. Although the altruist model can be treated as a special case of a bargaining model in which one spouse has a monopoly on bargaining power, I treat it separately because it represents a conceptually distinct approach to allocation within marriage.

Another difference between BAMM and BIM, important for the analysis of the marriage market as an institution, is that BIM allows Pareto inefficient equilibria while BAMM does not. With BIM, marriage market equilibria need not be Pareto efficient even if bargaining leads all couples to Pareto-efficient allocations within marriage, as it must with cooperative bargaining or the altruist model. The intuition is simple: with BIM or the altruist model, a husband with "too much" bargaining power can appropriate the lion's share of marital output. Of course this must leave his wife with at least as much as she would have if she left the marriage, but it can leave her with less than she would have if she had remained unmarried. Foreseeing this, a prospective wife would refuse such a marriage.

In section 1 I discuss marriage market equilibrium with BAMM and in section 2 marriage market equilibrium with BIM. Section 3 shows that BAMM and BIM can have different implications for both assortative marriage (i.e., who marries whom) and for who marries and who does not. Section 4 discusses three cases in which, it has been argued, marriage market equilibrium under BAMM and BIM coincide -- costless divorce, prenuptial agreements, and premarital transfers. I argue that none of these justify using BAMM to analyze marriage market equilibrium. Section 5 pulls together three loose ends: the Pareto efficiency of marriage market equilibrium, the need to distinguish between BAMM and BIM in search models, and the treatment of cohabitation 
as an alternative to marriage and to living alone. Section 6 is a brief conclusion. ${ }^{2}$

\section{Marriage Market Equilibrium with Binding Agreements in the Marriage Market (BAMM)}

The Beckerian analysis of marriage market equilibrium assumes that prospective spouses can make BAMM and that these agreements are costlessly enforceable. Because these agreements determine allocation within marriage, they leave no scope for BIM or for Becker's altruist model. Lam (1988), Choo and Siow (2006), Browning, Chiappori and Weiss (2014), and Siow (2015) provide important elaborations of the Beckerian model. I focus on Becker's original discussion because the more recent elaborations are irrelevant to and sometimes distract from the conceptual issues I raise.

Marriage market equilibrium has two related aspects: the matching or assignment of women to men (or, equivalently, of men to women) -- that is, who marries and who marries whom -- and the "payoffs" received by each marriage market participant. As McElroy (1997) argues, the marriage market literature has generally emphasized the matching or assignment aspect and has treated the payoffs primarily as a mechanism for achieving the equilibrium matching. With BAMM, the payoffs corresponding to marriage market equilibrium must satisfy conditions that relate the payoffs married individuals receive to the payoffs they would receive as unmarried individuals and to the payoffs they would be offered by other potential spouses. The comparison with the payoffs they would receive as unmarried individuals is an individual rationality condition: to enter marriage, individuals must receive payoffs at least as great as those they would receive as unmarried

\footnotetext{
${ }^{2}$ Following the mainstream of the marriage market literature, I restrict attention to heterosexual monogamous unions. Gale and Shapley (1962) distinguish between matching problems with two classes of agents (e.g., men and women; colleges and students; workers and firms) and those with one class of agents (e.g., the "roommate problem: An even number of boys wish to divide up into pairs of roommates.") They establish the existence of equilibrium in matching problems with two classes of agents and show that the conditions that ensure existence with two classes of agents do not ensure existence with one class of agents. Thus, the restriction to heterosexual unions reflects the mathematical requirements of matching models. Unlike the restriction to heterosexual unions, the restriction to monogamy is a modeling choice. The analysis of many-to-one matchings is well developed and there is ample precedent for considering polygamous marriage markets (Becker, 1991, p. 87). Indeed, Becker's Treatise on the Family begins the discussion of marriage with a chapter on "Polygamy and Monogamy in Marriage Markets," famously arguing that polygamy benefits women.
} 
individuals. An equilibrium assignment satisfies two additional conditions: (1) no one is willing to offer an unmarried individual enough to induce that individual to marry and (2) no one is willing to offer a married individual enough to bid that individual away from his or her assigned spouse.

Bids are binding. In the Treatise Becker writes: "The analysis of equilibrium sorting developed in this chapter has assumed that all divisions of outputs between mates are feasible" (1991, p. 126). This sentence should be read as a restatement of the assumption that prospective spouses can make binding agreements in the marriage market. Becker and Murphy (2000, Chapter 4) provide an explicit statement of the binding agreement assumption: "...the marriage market allows ... [unmarried individuals] to bid for different spouses by offering a larger or smaller share of the output they would produce together" (p. 31).

Becker's exposition of BAMM relies heavily on three auxiliary assumptions. First, although the bargaining process is unspecified, prospective spouses are assumed to bargain to Pareto efficient agreements. ${ }^{3}$ Cooperative bargaining ensures Pareto efficiency, but efficiency also can emerge from noncooperative bargaining. Competition in a marriage market in which all prospective spouses meet one another instantaneously places bounds on the set of payoffs that can emerge from bargaining and, in the limit, competition may entirely eliminate any role bargaining.

Second, Becker explicitly assumes that households produce a single output that must be allocated between the spouses. The single output assumption meshes well with the household production framework and with the emphasis on supermodularity in the analysis of assorative marriage. Becker asserts that his analysis does not require "transferable utility" or any other assumption about preferences. ${ }^{4}$ Shapley and Shubik (1971) show that the analysis applies not only with a single output but also with transferable utility; Bergstrom (1997) provides a thorough

\footnotetext{
${ }^{3}$ Farrell (1987) discusses the assumptions required to ensure that bargaining leads to Pareto efficient agreements.

${ }^{4}$ Becker (1973, p 816) writes: "Moreover, my concentration on the output and distribution of Z [the aggregate commodity] does not presuppose transferable utilities, the same preference function for different members of the same household, or other special assumptions about preferences."
} 
discussion of the model and of the interpretation of transferable utility.

Third, but less important than the other two auxiliary assumptions, Becker assumes "marriage dominance." Marriage dominance is the assumption that every possible marriage produces a "surplus" -- more than the sum of the outputs the spouses could produce as unmarried individuals. Becker provides a succinct statement of the marriage dominance hypothesis: “... the complementarity between men and women and the differences between their comparative advantages imply that both men and women are better off married..." (p. 110). I return to marriage dominance in section 3 when I discuss who marries and who does not.

The assignment model of Koopmans and Beckmann (1957) is the mathematical foundation of the Beckerian marriage market analysis with a single output or transferable utility. Koopmans and Beckmann analyze the problem of a social planner assigning industrial plants to locations so as to maximize total output. The statement of the problem presupposes that all plants produce the same product. Becker $(1973,1991)$ was the first to recognize that, with BAMM and a single output, the assignment model could be used to analyze marriage market equilibrium. The equilibrium matching maximizes the sum of outputs over all possible marriages and the Koopmans-Beckmann assignment model reduces the task of finding the equilibrium matching to a linear programming problem. That is, the output-maximizing assignment of spouses corresponds to equilibrium in a competitive market, where the "prices" are "imputations" in the dual of the social planner's maximization problem. Although the equilibrium matching is essentially unique, the corresponding payoffs or imputations (i.e., the division of output between spouses) are not. As the number and density of marriage market participants increases, however, the requirements of equilibrium in the marriage market place increasingly tight bounds on imputations.

The following numerical example, borrowed from Becker (1991, p. 111), involves 2 men and 2 women and illustrates the implications of BAMM with a single output and marriage 
dominance. The matrix showing the output of each of the four possible marriages is reproduced below:

$\begin{array}{ccc} & \text { F1 } & \text { F2 } \\ \text { M1 } & 8 & 4 \\ \text { M2 } & 9 & 7\end{array}$

The numbers in the matrix are the excess output over the sum of the outputs prospective spouses could produce as unmarried individuals. ${ }^{5}$ Referring to this example, Becker writes: "Although the maximum output of a marriage is produced by a marriage between M2 and F1, the optimal sorting is (M1, F1) and (M2, F2)" (1991, p. 111). He continues, "This example illustrates that the marriage market chooses not the maximum output of any single marriage but the maximum sum of the outputs over all marriages, just as competitive product markets maximize the sum of the outputs over all firms" (p. 112). ${ }^{6}$ As I show in section 3, the conclusion that the equilibrium sorting is (M1, F1) and (M2, F2) depends crucially on BAMM and need not hold with BIM or with Becker's altruist model.

With BAMM the crucial assumption is that bids are not cheap talk. Auxiliary assumptions substantially simplify the analysis and allow the use of the Koopmans-Beckmann assignment model, but BAMM requires neither Pareto-efficient bargaining in the marriage market, nor a single output, nor transferable utility, nor that all marriage market participants meet one another instantaneously. If we also assume marriage dominance, then the maximum number of (monogamous) marriages will form. Hence, with this assumption the analysis necessarily focuses on assortative marriage (i.e., who marries whom) rather than on who marries and who does not. But

\footnotetext{
${ }^{5}$ Although Becker refers to the elements of the matrix as "outputs," they are outputs only if we assume that all unmarried individuals produce 0 output.

${ }^{6}$ As this quotation makes clear, Becker is concerned not only with the planner's problem of optimal sorting but also with marriage market equilibrium.
} 
the conclusion that the maximum number of marriages will form depends not only on marriage dominance ("both men and women are better off married") but also on BAMM. That is, prospective spouses, when they meet in the marriage market, make binding agreements that specify each spouse's share of marital output.

\section{Marriage Market Equilibrium with Bargaining in Marriage (BIM)}

In their celebrated 1962 paper "College Admission and the Stability of Marriage" Gale and Shapley proposed and analyzed the first matching model. ${ }^{7}$ They assumed that each man has a ranking of all women and each woman a ranking of all men, treating remaining unmarried as an additional alternative ranked by all men and by all women. These rankings were primitives of the model.

I generalize Gale-Shapley by allowing the rankings to depend on the allocations individuals foresee resulting from BIM or from the altruist model. I assume that prospective spouses understand that allocation within marriage will be determined by BIM or, alternatively, by the altruist, and that they foresee the allocations that will emerge. Allocation within each possible marriage is rigid and inflexible in the sense that marriage market participants can do nothing to alter it. Hence, associated with each potential marriage partner is an allocation within that marriage. ${ }^{8}$

If each man associates an allocation with every possible marriage, he can rank the women in the marriage market. Similarly, if each woman associates an allocation with every possible marriage, she can rank the men in the marriage market. In general, these rankings depend on both the allocations and on the identity of the prospective spouse, but to facilitate comparisons with BAMM,

\footnotetext{
${ }^{7}$ Roth and Sotomayor (1990) provide the definitive exposition and analysis of matching models.

${ }^{8}$ Prenuptial agreements and premarital transfers affect allocation within marriage and, hence, from the perspective of marriage market participants, allocation within marriage is not completely rigid and inflexible. If such agreements or transfers were common, were used primarily to manipulate allocation within marriage, and led to BIM payoffs that mimicked BAMM imputations, then BAMM equilibrium would hold even though BIM determined allocation within marriage. In section 4 I argue that prenuptial agreements and premarital transfers are not common and are not used primarily to manipulate allocation within marriage and, hence, that they do not provide a plausible rationale for using BAMM to analyze marriage equilibrium.
} 
I assume they depend only on the allocations. Using these rankings, and treating remaining unmarried as an additional alternative available to both men and women, the Gale-Shapley matching model applies directly to the analysis of marriage market equilibrium.

Gale and Shapley proposed an intuitively appealing equilibrium concept for matching models, a "stable matching," defined by two properties:

(i) no married individual prefers being unmarried to his or her current assignment, and

(ii) no two individuals of opposite sexes prefer being married to each other to their current assignments. (This language covers the case in which the current assignment is being unmarried as well as the case in which it is being married.)

Because Gale and Shapley treat remaining unmarried as a marriage market assignment, they ensure that the marriage market participation constraint is satisfied: in a stable matching individuals are never assigned to marriages they regard as worse than remaining unmarried. Gale and Shapley showed that a stable matching exists if each individual's ranking is an ordering. ${ }^{9}$

Two additional points about marriage market equilibrium with BIM or the altruist model deserve mention. First, without additional assumptions, stable matchings (i.e., the equilibrium assignment of women to men) need not be unique. When there are multiple equilibria and individuals' preferences are strict, the payoffs associated with different stable matchings differ systematically. ${ }^{10}$ Second, the Gale-Shapley analysis does not depend on and is not simplified by assuming a single output or on transferable utility. I retain these assumptions only to facilitate comparisons between BAMM and BIM or the altruist model.

The Gale-Shapley model is compatible with all bargaining models that uniquely determine allocation within marriage. Nash bargaining, the workhorse of the family bargaining literature, is

\footnotetext{
${ }^{9}$ Stronger results such as the lattice structure of stable matchings depend on assuming that preferences are strict (i.e., ruling out indifference).

${ }^{10}$ Roth and Sotomayor investigate the systematic differences in payoffs when there are multiple equilibria. Eeckhout (2000) establishes a sufficient condition for uniqueness.
} 
the obvious example. Regardless of whether the threat point is external to the marriage (as in divorce-threat bargaining) or internal to the marriage (as in separate-spheres bargaining), Nash bargaining uniquely determines allocations in every possible marriage and, hence, allows us to apply the Gale-Shapley matching model. ${ }^{11}$ In Nash bargaining, the outside option and bargaining power are identical; in generalized Nash bargaining, they are distinct.

Early expositions of the "collective model" interpreted distribution within marriage as reflecting bargaining power in marriage, but more recent expositions have interpreted distribution as reflecting conditions in the marriage market. For example Browning, Bourguignon, Chiappori, and Lechene (1994) motivate the collective model's assumption of Pareto efficiency in marriage by noting that the marital environment possesses characteristics likely to promote efficient outcomes in repeated noncooperative games: a long-term relationship, relatively good information, and a stable bargaining environment. ${ }^{12}$ Browning, Chiappori, and Weiss (2014) argue that with costless divorce or the ability to make prenuptial agreements or premarital transfers, the marriage market equilibria with BAMM and BIM coincide. I discuss these claims in section 4.

Becker's altruist model, like bargaining models of marriage, leads to the Gale-Shapley matching model. In the altruist model one spouse -- for definiteness, the husband -- has the power to impose his preferred allocation, subject to his wife's participation constraint. Pollak (1985) argues that the altruist model is observationally equivalent to an ultimatum game in which the husband can confront the wife with a take-it-or-leave-it offer. The husband need not offer his wife more than her reservation payoff -- her payoff if she were to leave the marriage. If the husband has

\footnotetext{
${ }^{11}$ In divorce-threat models such as those of Manser and Brown (1980) and McElroy and Horney (1981), bargaining power depends on the payoffs of the spouses if the marriage were to end. In the separate-spheres model of Lundberg and Pollak (1993), bargaining power depends on a threat point that is internal to the marriage -- a noncooperative equilibrium that reflects control over resources and norms regarding gender roles.

${ }^{12}$ Lundberg and Pollak (2003) argue that Pareto efficiency is less plausible in dynamic environments where big up-front decisions (e.g., about where to live or whether to have another child) affect future bargaining power. And, as McElroy (1997) points out, because the collective model does not specify an explicit bargaining model, the analysis of bargaining power lies beyond its scope.
} 
the power to determine allocation within marriage subject to his wife's participation constraint, then the wife's payoff in marriage depends on this participation constraint, the resource constraint, and on the weight the husband places on the wife's well-being (i.e., how "altruistic" he is). Because the altruist model takes an ongoing marriage as its starting point, the relevant participation constraint depends on the cost of divorce, including the prospects for subsequent reentry into the marriage market. ${ }^{13}$ Viewed from the perspective of the marriage market, individual rationality implies that no one would enter a marriage unless the payoff were greater than the payoff from remaining unmarried. Viewed from the perspective of an ongoing marriage, individual rationality implies that no one would remain in a marriage unless the payoff was greater than the payoff from leaving. In the altruist model, a husband has the power to impose an allocation that is worse for the wife than remaining unmarried, provided the allocation would leave her better off than divorce.

\section{Implications of BAMM and BIM for Marriage Market Equilibrium}

BAMM, BIM, and the altruist model differ in their implications for who marries, for who marries whom, and for the payoffs to marriage market participants. In section 3A I discuss assortative marriage (i.e., who marries whom), and in section 3B who marries and who does not. All three marriage market models -- BAMM, BIM, and the altruist model -- provide internally consistent accounts of both allocation within marriage and marriage market equilibrium. Hence, the choice among them must turn on empirical rather than theoretical considerations -- on which provides the best account of allocation within marriage and marriage market equilibrium in a particular time and place.

\footnotetext{
${ }^{13}$ A careful reader will have noticed that there are two participation constraints: the "marriage market participation constraint" (i.e., the constraint facing unmarried individuals) and the "ongoing marriage participation constraint" (i.e., the constraint facing those currently married). With BAMM, allocation within marriage is determined in the marriage market and constrained by the marriage market participation constraint. With BIM or the altruist model, for those currently married, allocation within marriage is determined within marriage and constrained by the ongoing marriage participation constraint; for those currently unmarried, both participation constraints play roles in the decision to enter marriage.
} 


\section{A. Implications for Assortative Marriage}

Without acknowledging that he has done so, Becker reinterprets the Gale-Shapley model by allowing each man's ranking of women and each woman's ranking of men to depend on the division of output within marriage. ${ }^{14}$ Becker's reinterpretation is a significant innovation because it provides the bridge connecting the Gale-Shapley model and economics.

Becker then introduces an additional assumption that is a roadblock, vitiating the power of his innovation. Becker assumes that "all men receive the same fraction of output in all possible matches" (p. 126). If all men receive the same fraction of output in all possible matches, then the analysis of allocation within marriage becomes a project for anthropologists or sociologists, not for economists. Not surprisingly, the Gale-Shapley matching model plays no further role in the Treatise and Becker bases his analysis of marriage market equilibrium on BAMM and the Koopmans-Beckmann assignment model.

Becker contrasts BAMM, with its assumption of "flexible prices" with marriage market analysis based on the Gale-Shapley matching model which he describes as assuming that the division of output between spouses is "inflexible" (p. 126) or "rigid" (p. 133). Characterizing GaleShapley, Becker writes: "These [Gale-Shapley] models...assume...that the division of outputs in any marriage is not determined by the marriage market and is completely rigid" (p. 127). These two distinct assumptions -- "not determined by the marriage market" and "completely rigid" -- obscure Becker's innovation: the introduction of outputs and the division of output into the Gale-Shapley matching model.

\footnotetext{
${ }^{14}$ In Gale-Shapley these rankings are primitives of the model. Gale and Shapley describe the marriage problem in three concise sentences: "A certain community consists of n men and $n$ women. Each person ranks those of the opposite sex in accordance with his or her preferences. We seek a satisfactory way of marrying off all members of the community." The generalization to unequal numbers of men and women is straightforward.
} 
A modified version of Becker's numerical example illustrates the difference between BAMM and BIM. Becker's original matrix showing the output of each of the four possible marriages is given by

$\begin{array}{ccc} & \text { F1 } & \text { F2 } \\ \text { M1 } & 8 & 4 \\ \text { M2 } & 9 & 7\end{array}$

With BAMM, the equilibrium matches are those on the diagonal: (M1,F1) and (M2,F2).

With BIM, the equilibrium matches depend on allocation within each of the 4 possible marriages. The entries in the following matrix represent hypothetical allocations within each marriage corresponding to BIM. (From the standpoint of marriage market equilibrium, the specific bargaining model that leads to these allocations is irrelevant.) The first number in each parenthesis is the payoff to the husband (the row player) and the second the payoff to the wife (the column player). For each marriage, the sum of payoffs is the total shown in Becker's matrix.

F1 F2
M1 $(4.5,3.5)$
$(3,1)$
M2 $(5.0,4.0)$
$(4,3)$

In this example the equilibrium with BIM corresponds to the off-diagonal matches, (M2,F1) and (M1,F2). (Because (M2,F1) gives both M2 and F1 higher payoffs than any other marriage, they marry each other.) That is, in this example BAMM and BIM imply different patterns of assortative marriage. And, of course, we can reinterpret the payoffs in this example as emerging from the altruist model and conclude that BAMM and the altruist model can imply different patterns of assortative marriage. 


\section{B. Implications for Who Marries and Who Does Not}

The retreat from marriage of the past half century as well as what historical demographers call the "European marriage pattern" signal the need to treat nonmarriage as a feature of marriage market equilibrium. Yet economists studying marriage markets have virtually ignored nonmarriage and focused almost exclusively on the pattern of assortative marriage (i.e., among those who marry, who marries whom). After briefly discussing the late 20th century retreat from marriage and the European marriage pattern, I compare the implications of BAMM with those of BIM and the altruist model for who marries and who does not. With marriage dominance, there are at least as many marriages with BAMM as with BIM or the altruist model.Without marriage dominance, however, there may be more marriages with BIM or the altruist model.

The retreat from marriage since the 1950s is well documented. The United States and other developed countries have experienced delayed marriage and rising propensities to divorce. Comparing US cohorts born in 1950-55 with those born in 1957-64, the fraction ever married by their mid 40s declined from 89.5 percent to 86.8 percent. ${ }^{15}$ Increases in the relative wages of women, improvements in household technology, greater availability of market substitutes for commodities that were traditionally produced within the household, and increased social and legal acceptability of cohabitation and nonmarital fertility have reduced the importance of gains to marriage based on the traditional gendered pattern of specialization and exchange. ${ }^{16}$ As the importance of the traditional gains to marriage has decreased, the returns to parental investment in children's human capital have increased. Lundberg and Pollak $(2014,2015)$ and Lundberg, Pollak

\footnotetext{
${ }^{15}$ Aughinbaugh, Robles, and Sun (2013) calculate the figures for the 1957-64 cohort from the National Longitudinal Survey 1979 (NLSY79) for those ever married by age 46. Stevenson and Wolfers (2007) calculate the figures for the 1950-55 cohort from the Survey of Income and Program Participation (SIPP) for those ever married by age 45. For recent changes in marriage, divorce, cohabitation, and childbearing in the US, see Bailey, Guldi, and Hershbein (2014), Kennedy and Ruggles (2014), Lundberg and Pollak (2014, 2015), Lundberg, Pollak and Stearns (2016), and Stevenson and Wolfers (2007); for Europe, see Klüsener, PerelliHarris, and Sánchez Gassen (2013), and Perelli-Harris et al., (2010).

${ }^{16}$ In contrast to the usual emphasis on gender specialization and production complementarities as the source of gains to marriage, Stevenson and Wolfers (2007) emphasize the increasing importance of consumption complementarities ("hedonic marriage").
} 
and Stearns (2016) argue that couples, especially college graduate couples, use marriage as a commitment device to bind themselves and each other to a strategy of high levels of joint investment in their children.

Before the retreat from marriage of the past half century became evident, historical demographers identified a European marriage pattern characterized by a high proportion of both men and women who never marry. The demographer John Hajnal (1965), describing Europe for two centuries prior to 1940, wrote: “The distinctive marks of the 'European' pattern are (1) a high age at marriage and (2) a high proportion of people who never marry at all” (p. 101). Hajnal acknowledged that the marriage pattern he identified might more accurately be described as the "Western European pattern." He wrote: "The European pattern extended all over Europe to the west of a line running roughly from Leningrad (as it is now called) to Trieste." ${ }^{, 17}$ Lee and Feng (1999) contrast the Chinese marriage pattern with the European pattern: "While 15 percent of Western females continue to remain unmarried at age 40 , only 1 percent of Chinese females are unmarried at age 30" (pp. 67-68). ${ }^{18}$

Unlike demographers, economists have paid little attention to nonmarriage except when discussing polygyny or when there are unequal numbers of men and women. Indeed, an auxiliary assumption often imposed in the standard marriage market model, BAMM, implies that in equilibrium there cannot be both unmarried men and unmarried women, a property I call "universal marriage." With BAMM universal marriage follows from "marriage dominance" -- the assumption that any man and any woman would produce more as a married couple than the sum of the outputs they would produce as unmarried individuals. We can restate marriage dominance by saying that every possible marriage produces a "surplus" -- where the surplus is defined as the difference

\footnotetext{
${ }^{17}$ Wrigley (2014) surveys subsequent research on the European marriage pattern.

${ }^{18}$ Lee and Feng (1999, p 68, Table 2) show the percentage of Chinese women never married by age 30 for various locations from the 17 th century to the present. The percentages range from 0 to 4 percent.
} 
between the output of the marriage and the sum of the outputs the spouses would produce as unmarried individuals. ${ }^{19}$

With BIM, the number of marriages depends on allocation within marriage as well as on the productivity of marriage compared with the productivity of unmarried individuals. Hence, with BIM, marriage dominance does not imply universal marriage. Unless the allocation that would emerge from BIM would make both prospective spouses better off (or at least not worse off) than they would be if the couple did not marry, they will not marry. Indeed, even with marriage dominance, BIM is consistent with marriage market equilibria in which no one marries even though all marriages produce a surplus. (Suppose that in each possible marriage the man prefers an allocation that would make the woman worse off than nonmarriage, and that husbands have sufficient bargaining power to impose this allocation. Realizing this, the women refuse to marry so that in equilibrium no one marries.)

With marriage dominance and BAMM, the maximum possible number of marriages form; hence, with marriage dominance, at least as many marriages form with BAMM as with BIM. Without marriage dominance, however, there may be more marriages with BIM. Consider the following 2 x 2 example in which one of the four possible marriages -- in this example (M2,F2) -fails to produce a surplus.

$\begin{array}{ccc} & \text { F1 } & \text { F2 } \\ \text { M1 } & 20 & 5 \\ \text { M2 } & 5 & -1\end{array}$

With BAMM, there is only one marriage: (M1, F1). With BIM, marriage market equilibrium depends on allocations within each possible marriage. Suppose that BIM would lead to the following allocations:

\footnotetext{
${ }^{19}$ The notions of marriage dominance and surplus extend readily from the single output case to transferable utility. Later in this section I reformulate marriage dominance to avoid these restrictions.
} 
M2 $(2,3) \quad(-.5,-.5)$

With these allocations, two marriages will form: (M1, F2) and (M2, F1). Hence, in this example, BIM leads to more marriages than BAMM.

Because the altruist model can be interpreted as a polar case of a bargaining model in which one spouse has all the bargaining power, the argument above shows that the altruist model can also lead to more marriages than BAMM. That is, with marriage dominance, at least as many marriages form with BAMM as with the altruist model, but without marriage dominance more marriages may form with the altruist model than with BAMM.

Nonmarriage has two possible explanations: an empty "bargaining set" and "contracting problems," that is, the inability of prospective spouses to make binding agreements in the marriage market. ${ }^{20}$ With a single output or transferable utility the bargaining set is nonempty if the marriage generates a surplus -- meaning, in the single output case, that the marriage produces more than the sum of the outputs the spouses could produce as unmarried individuals. To generalize marriage dominance beyond the single output or transferable utility cases, imagine a social planner determines allocation within each marriage, subject to the resource constraints corresponding to the couple's resources and technology. The generalization of marriage dominance postulates that, for any man and any woman, there are gains to marriage in the sense that the social planner could find an allocation that both prospective spouses would prefer to never marrying. This definition of generalized marriage dominance requires neither a single output, nor transferable utility, nor any

\footnotetext{
${ }^{20}$ A third possible explanation, search frictions, is ruled out by the assumption that everyone in the marriage market meets everyone else instantaneously.
} 
other restriction on preferences. Whether the bargaining set is empty is independent of whether allocation within marriage is determined by BAMM, BIM or the altruist model. With BAMM, and without the intervention of a social planner, prospective spouses can attain all allocations in the bargaining set. Hence, with BAMM generalized marriage dominance implies universal marriage. With BIM or the altruist model, however, at most one of these allocations is attainable, so BIM and generalized marriage dominance do not imply universal marriage.

An empty bargaining set for some subset of possible marriages is plausible. Because the traditional sources of gains from marriage have weakened over the past 60 years, it is more likely now than in the past that the bargaining set corresponding to the marriage of a randomly chosen man with a randomly chosen woman will be empty. For example, for many of the severely disadvantaged unmarried parents described in Edin and Nelson (2013), the bargaining set appears to be empty.

With marriage dominance, only contracting problems can explain the presence of both unmarried men and unmarried women in marriage market equilibrium. BIM and the altruist model are consistent with contracting problems, while BAMM is not. Under US law, provisions of contracts specifying allocation within marriage are not legally enforceable. In section 4B I discuss how the provisions of prenuptial agreements that are legally enforceable influence allocation within marriage.

In the absence of legally enforceable agreements, self-enforcing agreements, informal rules and social norms must play crucial roles. Lundberg and Pollak (2007, p. 16) suggest that the weakening of traditional gender roles over the past half century has reduced the ability of couples to make self-enforcing agreements (e.g., regarding sexual fidelity, the sharing of child care responsibilities) in part because the traditional gender-based division of labor is no longer a selfenforcing Nash equilibrium. Even if norms are sticky and lag behind changes in the relative earning 
capacities of men and women, in the long run norms may adjust to new economic and social realities. If they do, then the retreat from marriage may be a disequilibrium phenomenon. ${ }^{21}$

The social science literature provides some support for the hypothesis that contracting problems explain some portion of the retreat from marriage. Furstenberg (2001) points to a breakdown in the consensus regarding appropriate gender roles as a barrier to marriage, particularly for African-Americans. Sevilla-Sanz (2005) suggests that peer pressure is likely to provide support for traditional gender roles. Edin and Kefalas $(2005$, p. 118) report that poor women fear that marriage "activates traditional gender roles" and choose to maintain their independence by not marrying the fathers of their children. Ethnographic research emerging from the Fragile Families Study finds that unmarried mothers identify "lack of trust" and, in particular, fear of male infidelity, as a major barrier to marriage (Gibson-Davis, Edin, and McLanahan, 2005). Contracting problems may also explain the low marriage and fertility rates in Japan and Southern Europe. Sevilla-Sanz (2010) shows that these are countries with conservative gender norms in which women's education levels and wage rates have risen rapidly. Although economists might expect to see departures from the traditional gendered division of childcare and other household tasks, these countries have instead experienced sharp declines in marriage and in fertility. These declines may reflect contracting problems -- the inability of prospective spouses to make binding agreements in the marriage market. But they may instead reflect an empty bargaining set: departures from traditional gender roles that would make marriage acceptable to young women might make it unacceptable to young men.

The extent to which the retreat from marriage reflects an empty bargaining set rather than the inability of prospective spouses to make binding agreements in the marriage market is an open question the answer to which may differ from one country to another and, within countries, from

\footnotetext{
${ }^{21}$ Goldscheider, Bernhardt, and Lappegård, (2015) reach a similar conclusion by a different route.
} 
one group to another. Indeed, even for cohabiting couples with joint children, we do not know the extent to which nonmarriage reflects the reluctance of fathers rather than the reluctance of mothers to marry.

\section{Costless Divorce, Prenuptial Agreements, and Premarital Transfers}

The BIM marriage market equilibrium coincides with the BAMM marriage market equilibrium for the "right" configuration of bargaining power. Browning, Chiappori and Weiss (2014, pp. 311-314) argue that prospective spouses can use prenuptial agreements and premarital transfers to manipulate bargaining power. This possibility, they argue, provides a rationale for using BAMM to analyze marriage market equilibrium even when BIM determines allocation within marriage. I disagree. This section is a response to their argument.

There are several difficulties. The threshold difficulty is that in order for the BIM equilibrium to mimic the BAMM equilibrium the configuration of bargaining power must lead to a pattern of payoffs that mimics the BAMM imputations. This does not imply that all couples must make prenuptial agreements or premarital transfers -- indeed, with no such agreements or transfers, the BIM payoffs may happen to mimic the BAMM imputations. The amount of manipulation required to align BIM payoffs with BAMM imputations depends on the "distance" between the unmanipulated BIM payoffs and the BAMM imputations.

The ability of prospective spouses to use prenuptial agreements and premarital transfers to manipulate the BIM payoffs implies that these payoffs are not as "rigid and inflexible" as I have thus far assumed. Yet it is implausible that prenuptial agreements or premarital transfers will lead to a pattern of payoffs that mimic BAMM imputations for two reasons. The first is empirical: few couples make prenuptial agreements and premarital transfers. The second is theoretical: in addition to making prenuptial agreements or premarital transfers, the terms of the agreements and the magnitudes of the transfers must be calibrated to achieve the payoffs required to mimic the BAMM 
imputations. The conventional wisdom, however, is that couples making such agreements or transfers typically do so to protect the interests of children from previous relationships or to protect their own interests in the event of divorce, not to manipulate allocation within marriage. Hence, it is unlikely, although not impossible, that prenuptial agreements and premarital transfers will lead to the pattern of payoffs required to mimic the BAMM imputations. This is not to deny the possibility that premarital agreements or premarital transfers could conceivably manipulate bargaining power so that BIM payoffs would mimic BAMM imputations. The issue is whether this possibility is great enough to justify BAMM analysis in a BIM world.

Browning, Chiappori and Weiss also argue that costless divorce will lead to BIM payoffs that mimic BAMM imputations. The difficulty here that costless divorce is an oxymoron: costless divorce negates commitment, and commitment is the essential feature that distinguishes marriage from cohabitation and cohabitation from casual sex. Furthermore, to replicate the BAMM equilibrium requires not only costless divorce but also "costless" reentry into the marriage market -that is, divorced individuals must be able to reenter the marriage market on the same terms as before they were married.

I discuss costless divorce in section $4 \mathrm{~A}$, prenuptial agreements in section $4 \mathrm{~B}$, and premarital transfers in section $4 \mathrm{C}$.

\section{A. Costless Divorce}

The assumption of "costless divorce," which I interpret broadly to include "costless reentry" into the marriage market, makes BAMM and BIM equivalent by assuming away commitment. Becker (1991, p. 30/31) provides a clear statement of the traditional rationale for commitment in marriage and posits that marriage is defined by long-term commitment: "Since married women have been specialized to childbearing and other domestic activities, they have demanded long-term 'contracts'

from their husbands to protect them against abandonment and other adversities. Virtually all 
societies have developed long-term protection for married women: one can even say that 'marriage' is defined by a long-term commitment between a man and a woman." Although divorce has become less costly over the past 60 years, long-term commitment remains an essential feature of marriage. Marriage functions as a commitment device only because divorce is costly.

Costless reentry into the marriage market means that prospective spouses do not distinguish between previously-married and never-married individuals. A more fundamental distinction is arguably between parents and nonparents and, among parents, between custodial and noncustodial parents. Reentry into the marriage market is no doubt easier for women without children than for mothers, especially mothers with custody of minor children. Similarly, reentry is presumably easier for men, especially men with neither custody of minor children nor child support obligations. Because mothers are more likely than fathers to be custodial parents, and because children are more readily observable than child support obligations, reentry into the marriage market is likely to be more difficult for mothers than for fathers. But the difficulty of reentry presumably also depends on the fraction of those seeking to (re)enter the marriage/ partner market who also have custody of children or child support obligations.

Prior to the mid-19th century, divorce was very rare. For example, Stone (1990) writes: "It must never be forgotten that England in the early modern period was neither a separating nor a divorcing society: death was virtually the sole agent for dissolving marriage" (p. 2). Becker cites Rowntree and Carrier for the fact that "There were fewer than two (!) divorces per year in England from 1800 to $1850 . . . "$ (1991, p. 374, Becker's exclamation point). The 1857 Divorce Act substantially liberalized divorce law in England and Wales, yet the number of divorces per year remained under 1000 until the First World War (see Stone (1990, Table 13.1)). The liberalization of divorce law in England and the United States in the mid 19th century did not permit married couples to dissolve 
their marriages by mutual consent. ${ }^{22}$

At least in theory, in every US state prior to 1970 divorce required a finding of fault (e.g., adultery; a felony conviction; cruelty). In practice, there were substantial differences among states and over time in the difficulty of getting a divorce and spouses who wanted to divorce would often collude to obtain a fault-based divorce. The landscape changed with the "divorce revolution" that included various combinations of no-fault and unilateral divorce. No-fault divorce first became available in California in 1970 and most other states followed suit rapidly. New York, the last state to adopt no-fault divorce, did so in $2010 .^{23}$

B. Prenuptial Agreements

Prenuptial agreements cannot specify allocation within marriage or, more precisely, US courts will not enforce such provisions. Courts will oversee the dissolution of marriages, but they will not supervise ongoing marriages. The legal scholar Saul Levmore (1995) memorably characterizes this rule as "love it or leave it." ${ }^{24}$ The legally enforceable provisions of prenuptial agreements are those specifying the disposition of assets following the death of a spouse and the division of income and assets following divorce. Of course, these legally enforceable provisions of prenuptial agreements do affect allocation within marriage.

Prenuptial agreements were originally about the disposition of assets following the death of a spouse and could not be used to contract around state divorce laws. The ability of prospective spouses to enter into enforceable agreements that constrain the authority of courts to specify the terms of divorce is less than 50 years old, and such agreements cannot limit the authority of courts

\footnotetext{
${ }^{22}$ Desertion, however, was an outside option, especially in 19th century America. Hartog (2000) writes, "The United States was an unimaginably large country, and many could disappear permanently from discarded pasts.... Bigamy or, rather, serial monogamy (without divorce or death) was a common social experience in early America" (p. 87).

${ }^{23}$ For a discussion of the effect of no-fault and unilateral divorce on divorce rates and references to the extensive literature, see Stevenson and Wolfers (2007).

${ }^{24}$ Hartog (2000) provides a fascinating account of McGurie v. McGuire, the case usually cited for the proposition that courts will not intervene in ongoing marriages. Whether such provisions should be enforceable is debated (see, for example, Case (2011) and Pollak (2011).
} 
to decide on child custody and child support. The legal scholar Jill Hasday (2014) writes: "Before the 1970s, courts often refused to enforce agreements that determined in advance how spouses would divide assets and pay support at divorce. Judicial opinions declared that such agreements were contrary to public policy and void on the theory that the agreements anticipated and facilitated divorce" (p. 75; footnotes citing cases omitted).

In the absence of a prenuptial agreement, state divorce laws specify the default terms for ending a marriage. Rosenbury (2005) finds that divorce laws differ substantially across states and that the differences go well beyond the distinction between community property and separate property states. ${ }^{25}$ Most separate property states require "equitable distribution" of "marital property" following divorce, but Rosenbury emphasizes that the definition of marital property differs from one state to another. Prenuptial agreements allow prospective spouses to contract around the provisions the divorce laws of their state. In the light of empirical research establishing the importance of default rules in other contexts, it is no surprise that prospective spouses seldom make prenuptial agreements. ${ }^{26}$

The threshold difficulty with invoking prenuptial agreements to argue that the BAMM marriage market equilibrium will hold when BIM determines allocation within marriage is empirical: few prospective spouses make prenuptial agreements. The conventional wisdom is that in first marriages about 5 percent of couples make prenuptial agreements, and that in second and higher order marriages this figure rises to about 20 percent. These figures are suspect. Marston (1997), an article in the Stanford Law Review, is often cited for both figures. She attributes the 5 percent figure to Belsky (1996), an article in Money magazine, which cites no source. She attributes the 20 percent figure to Sigler (1994), an article in the Connecticut Probate Law Journal that

\footnotetext{
${ }^{25}$ The 9 community property states are Arizona, California, Idaho, Louisiana, Nevada, New Mexico, Texas, Washington, and Wisconsin.

${ }^{26}$ On default rules, see, for example, Beshears, Choi, Laibson, and Madrian (2009) or, for a popular account, Thaler and Sunstein (2008).
} 
attributes the 20 percent figure to Stark (1993), an article in Money magazine, which cites no source.

Prenuptial agreements can now specify the disposition of assets following the death of a spouse and the division of assets and sometimes the division of earnings following divorce. Anecdotal evidence suggests that prenuptial agreements are used primarily by wealthy prospective spouses seeking to protect the inheritance interests of their children from previous relationships or to protect their own interests in the event of divorce. Prenuptial agreements designed primarily for these purposes also affect allocation within marriage, but we would not expect prenuptial agreements intended to protect children from previous marriages or to protect prospective spouses in the event of divorce would also replicate the allocations corresponding to BAMM.

A theoretical analysis of the effect of prenuptial agreements on allocation within marriage requires specifying a bargaining model or a class of such models. With divorce-threat bargaining, as the name suggests, divorce is both the outside option and the threat point. The theoretical difficulty with divorce-threat bargaining models is the assumption that a spouse whose current allocation is more favorable than divorce can use the threat of divorce to bargain for even more favorable allocation. In the language of noncooperative game theory, such a threat lacks credibility. ${ }^{27}$ Thus, the claim that prenuptial agreements provide a mechanism that prospective spouses can use to control allocation within marriage implicitly assume divorce-threat bargaining while failing to address the credibility of the divorce threat.

In other bargaining models, such as Generalized Nash bargaining or the separate spheres bargaining model of Lundberg and Pollak (1993), divorce is not the threat point and prenuptial agreements operate only through the outside option. In such models, prenuptial agreements affect allocation within marriage only by restricting the set of bargaining solutions that satisfy individual

\footnotetext{
${ }^{27}$ Less formally, the legal scholar Robert Ellickson $(2006,2008)$ argues that what he calls the "end game" is relatively unimportant in ongoing marriages and other coresidential unions.
} 
rationality.

C. Premarital Transfers

As with prenuptial agreements, the threshold difficulty with invoking premarital transfers to argue that BAMM results hold when BIM determines allocation within marriage is empirical. We can imagine a world in which premarital transfers are common, but there is no evidence that they are in ours.

Premarital transfers raise interesting theoretical issues because they operate not only through the outside option but also through bargaining power. I distinguish between the case in which prospective spouses have sufficient initial wealth to make the transfers required to replicate the allocation corresponding to BAMM and the case in which they do not. If prospective spouses have sufficient initial wealth to make the premarital transfers required to achieve the BAMM allocation, one prospective spouse simply makes a gift to the other. If the couple subsequently marries, then one effect of the transfer is to alter the distribution of assets in the event of divorce (i.e., the premarital transfer changes the outside option). The other effect is to alter bargaining power within marriage through the effect on control over resources within marriage: during the life of the marriage, the premarital transfer converts investment income of one spouse into investment income of the other.

If a prospective spouse -- for definiteness, the husband -- lacks sufficient initial wealth to make the required premarital transfers, he can borrow against his future earnings to make the required transfer, thus converting his future labor income into his wife's future investment income. When the borrowing rate exceeds the rate of return at which she can invest, however, borrowing to make the premarital transfer reduces the couple's income.

Prospective spouses contemplating premarital transfers might seek to protect themselves with premarital contracts (e.g., specifying what would happen if the marriage failed to take place or 
lasted only briefly), and such contracts might be similar in complexity to prenuptial agreements. Premarital transfers also have tax or at least tax reporting consequences. ${ }^{28}$

\section{Three Loose Ends}

In this section I first discuss the Pareto efficiency of marriage market equilibrium (section $5 \mathrm{~A}$ ) and then the relevance of the distinction between BAMM and BIM in search models (section 5B). In section 5C I sketch a generalization of the marriage market analysis from situations in which there are two alternative living arrangements (e.g., living alone; marriage) to situations in which there are three alternative living arrangements (e.g., living alone, cohabitation, and marriage).

\section{A. Pareto Efficiency}

Pareto efficiency is a central concern of economics. With BAMM Pareto efficiency of both marriage market equilibrium and allocation within marriage follow from the twin assumptions that prospective spouses can make binding agreements and that bargaining leads to Pareto efficient allocations. With BIM and the altruist model, inefficient marriage market equilibria are possible even if allocation in every possible marriage is Pareto efficient. Indeed, because we know that BAMM maximizes the sum of outputs over all possible marriages, if BAMM and BIM imply different marriage market equilibria, then the pattern corresponding to BIM must be Pareto inefficient. The same reasoning applies to BAMM and the altruist model.

With BIM, if bargaining is a cooperative game, then the Pareto efficiency of allocation within each marriage is guaranteed. If, on the other hand, bargaining is noncooperative, then allocation within marriage may be Pareto inefficient. Hence, with BIM Pareto efficiency may fail for one or both of two reasons: because of inefficiency in allocation within marriage or because of inefficiency

\footnotetext{
${ }^{28}$ In the US, the gift tax and the estate tax are integrated to limit the ability of wealthy individuals to avoid estate taxes by making inter vivos transfers. In 2016 the US federal estate tax applies only to estates over $\$ 5.45$ million for an individual; gifts to any person other than a spouse totaling in excess of $\$ 14,000$ in a single year must be reported to the Internal Revenue Service. Thus, individuals wealthy enough to be concerned about the estate tax consequences of transfers may prefer prenuptial agreements to premarital transfers.
} 
in the marriage market. ${ }^{29}$ With the altruist model, allocation within every possible marriage is Pareto efficient, so the only possible source of inefficiency is the marriage market.

B. Search

The distinction between BAMM and BIM is crucial in search models as well as in marriage markets in which participants meet one another instantaneously. BAMM and BIM can imply different equilibria, although the details depend on the search protocol. The "one draw" search specification of Konrad and Lommerud (2010) provides a transparent and tractable illustration because it assumes away most of the complications of search and allows us to focus on the interactions between prospective spouses when they meet in the marriage market. In the one-draw specification, a man and a woman are drawn at random and offered a take-it-or-leave-it choice: marry each other or never marry. With BAMM, marriage dominance, and the usual Coasian assumption about bargaining, every randomly chosen couple will agree on an allocation that both prefer to remaining unmarried. Without marriage dominance, they will agree on an allocation and marry if the bargaining set is nonempty. In the one-draw specification, all allocations in the bargaining set are possible equilibria. With BIM, even if bargaining in marriage will lead to a Pareto efficient allocation, the allocations prospective spouses foresee emerging from bargaining in marriage may be worse for one of them than never marrying. A similar possibility arises with the altruist model.

C. Cohabitation

Virtually all marriage market models ignore cohabitation. ${ }^{30}$ The standard theory of marriage recognizes only two possible living arrangements: "marriage" and "living alone." In this section I

\footnotetext{
${ }^{29}$ Lundberg and Pollak (2003) argue that inefficient allocation within marriage is especially plausible in dynamic settings in which bargaining power in later periods depends on actions taken in earlier periods and spouses are unable to make binding agreements within marriage.

${ }^{30}$ Indeed, virtually all economic discussions of marriage ignore cohabitation. Exceptions include Brien, Lillard, and Stern (2006), Lundberg and Pollak (2014, 2015) and Lundberg, Pollak, and Stearns (2016).
} 
sketch a generalization of the dichotomous matching model to a trichotomous model, treating cohabitation as an additional living arrangement, distinct from both marriage and living alone. The existence of equilibrium in the trichotomous framework follows from essentially the same argument used in the dichotomous framework.

We can reinterpret the trichotomous framework as one in which couples choose between living alone and two forms of marriage. In Arizona, Arkansas, and Louisiana marrying couples choose between "standard marriage" and "covenant marriage," an option that requires premarital counseling and makes ending marriage more difficult by limiting the grounds for divorce. ${ }^{31}$ In France and in Italy, marrying couples must choose between two marital property regimes: common (i.e., community) property and separate property. ${ }^{32}$

BAMM generalizes in the obvious way to a trichotomous model in which allocation in each possible match is determined by binding agreements in the matching market. To generalize BIM, first consider the case in which preferences are primitives of the model and in which each woman (man) has preferences not simply over men (women) but over whether the match with a particular man (women) is marriage or cohabitation. For example, if there are two men, the preferences of a woman might be

$$
\begin{aligned}
& \text { marry man } 1 \\
& \text { cohabit with man } 2 \\
& \text { live alone } \\
& \text { cohabit with man } 1 \\
& \text { marry man } 2
\end{aligned}
$$

If there are $\mathrm{N}_{\mathrm{m}}$ men, each woman ranks $2 \mathrm{~N}_{\mathrm{m}}+1$ alternatives (marriage to each man; cohabitation with each man; living alone). Similarly, each man has preferences not simply over women but over

\footnotetext{
${ }^{31}$ For covenant marriage, see Cherlin (2009).

${ }^{32}$ For France, see Laferrère (2001); for Italy, Bayot and Voena (2015).
} 
whether the match type is marriage or cohabitation. If there are $\mathrm{N}_{\mathrm{f}}$ women, then each man ranks $2 \mathrm{~N}_{\mathrm{f}}$ +1 alternatives. In a different context, Hatfield and Milgrom (2005) show that under these assumptions the Gale-Shapley deferred acceptance algorithm converges, establishing the existence of a stable matching.

Now suppose the rankings are not primitives of the model but depend on the type of union (i.e., marriage or cohabitation) and on allocations that matching market participants foresee emerging from bargaining in each possible marriage and in each possible cohabitation. ${ }^{33}$ Under these assumptions, each woman (man) has a ranking of the $2 \mathrm{~N}_{\mathrm{m}}+1$ alternatives (marriage to each man; cohabitation with each man; living alone). Similarly, each man has a ranking over the $2 \mathrm{~N}_{\mathrm{f}}+1$ alternatives. Thus, the dichotomous matching model based on bargaining in each possible marriage generalizes to a trichotomous matching model based on bargaining in each possible match type.

\section{Conclusion}

The standard Beckerian analysis assumes that prospective spouses make binding agreements in the marriage market (BAMM) and that these agreements determine allocation within marriage. The alternative approaches, bargaining in marriage (BIM) and the altruist model, assume that allocation within marriage is determined within marriage rather than before marriage.

With BAMM and a single output or transferable utility, the appropriate framework for analyzing marriage market equilibrium is the Koopmans-Beckmann assignment model. With BIM, or the altruist model, the marriage market is the first stage of a two-stage game that must be solved by backwards induction. The second stage, BIM or the altruist model, determines allocation within each marriage. Marriage market participants' rankings of prospective spouses depend on the allocations they foresee emerging from bargaining. The first stage, the marriage market itself, determines who marries and who does not and, for those who marry, it determines who marries 
whom (assortative marriage). With BIM or the altruist model, the appropriate framework for analyzing marriage market equilibrium is the Gale-Shapley matching model. The analysis does not require and is not substantially simplified by assuming a single output or transferable utility.

Gale and Shapley treated individuals' rankings of prospective spouses as primitives of the model. Becker reinterpreted the Gale-Shapley model to allow rankings to depend on allocation within marriage, but Becker's reinterpretation of Gale-Shapley also assumed that the division of marital output between husbands and wives is the same in all marriages. On the basis of this identical division assumption, Becker dismissed the Gale-Shapley model as unsuitable for analyzing marriage market equilibrium. But requiring the same division across all couples is an arbitrary and unnecessarily restriction. Allowing the rankings to depend on the allocations that individuals foresee emerging from bargaining in each possible marriage, I analyze marriage market equilibrium using the Gale-Shapley matching model. I show that BAMM, BIM, and the altruist model can have different implications for who marries and, among those who marry, for who marries whom.

\footnotetext{
${ }^{33}$ Rankings can also depend on the identity of the prospective spouse/partner.
} 


\section{References}

Attanasio, Orazio and Valérie Lechene, "Tests of Income Pooling in Household Decisions," Review of Economic Dynamics, Vol. 5, No. 4, (October 2002), 720-748.

Aughinbaugh, Alison, Omar Robles, and Hugette Sun, "Marriage and Divorce: Patterns by Gender, Race, and Educational Attainment," Monthly Labor Review, Vol. 136, No. 10, (October 2013).

Bailey, Martha J., Melanie Guldi, and Brad J. Hershbein, "Is There a Case for a 'Second Demographic Transition'? Three Distinctive Features of the Post-1960 U.S. Fertility Decline," in Leah P. Boustan, Carola Frydman, and Robert A. Margo, eds. Human Capital and History: The American Record. Chicago: University of Chicago Press, 2014, 273-312.

Bayot, Denrick and Alessandra Voena, "Prenuptial Contracts, Labor Supply and Household Investments," June 2015.

Becker, Gary S., “A Theory of Marriage: Part I,” Journal of Political Economy, Vol. 81, No. 4, (July/August 1973), 813-46.

Becker, Gary S., A Treatise on the Family, Cambridge: Harvard University Press, 1981; Enlarged edition, 1991.

Becker, Gary S. and Kevin M. Murphy, Social Economics: Market Behavior in a Social Environment, Cambridge: Harvard University Press, 2000.

Bergstrom, Theodore C., "A Fresh Look at the Rotten Kid Theorem - and Other Household Mysteries," Journal of Political Economy, Vol. 97, No. 5 (October 1989), 1138-1159.

Bergstrom, Theodore C., "A Survey of Theories of the Family," in Mark R. Rosenzweig and Oded Stark, eds., Handbook of Population and Family Economics, Vol., 1A. Amsterdam: North-Holland Publishing Company, 1997, 21-79.

Belsky, Gary, "Living by the Rules," Money, Vol. 25, No. 5, (May 1996), 100.

Beshears, John, James J. Choi, David Laibson, and Brigitte C. Madrian, "The Importance of Default Options for Retirement Saving Outcomes: Evidence from the United States," in Social Security Policy in a Changing Environment, ed. by Jeffrey R. Brown, Jeffrey B. Liebman, and David A. Wise, Chicago: University of Chicago Press, 2009, 167-195.

Brien, Michael J., Lee A. Lillard, and Steven Stern, "Cohabitation, Marriage, and Divorce in a Model of Match Quality," International Economic Review, Vol. 47, No. 2, (May 2006), 451-494.

Browning, Martin, François Bourguignon, Pierre-André Chiappori, and Valérie Lechene, "Income and Outcomes: A Structural Model of Intrahousehold Allocation," Journal of Political Economy, Vol. 102, No. 6, (December 1994), 1067-1096.

Browning, Martin, Pierre-André Chiappori, and Yoram Weiss, The Economics of the Family, New York: Cambridge University Press, 2014. 
Case, Mary Anne, "Enforcing Bargains in an Ongoing Marriage," Washington University Journal of Law and Policy, Vol. 35 (2011), 225-260.

Cherlin, Andrew J., The Marriage-Go-Round, New York: Alfred A. Knopf, 2009.

Choo, Eugene and Aloysius Siow, "Who Marries Whom and Why," Journal of Political Economy, Vol. 114, No. 1, (February 2006), 175-201.

Doss, Cheryl, "Intrahousehold Bargaining and Resource Allocation in Developing Countries," World Bank Research Observer, Vol. 28, No. 1, (February 2013), 52-78.

Duflo, Esther, "Child Health and Household Resources in South Africa: Evidence from the Old Age Pension Program," American Economic Review, Vol. 90, No. 2, (May 2000), 393-398.

Duflo, Esther, "Grandmothers and Granddaughters: Old-Age Pensions and Intra-household Allocation in South Africa," World Bank Economic Review, Vol. 17, No. 1, (January 2003), 1-25.

Duflo, Esther, "Women Empowerment and Economic Development," Journal of Economic Literature, Vol. 50, No. 4, (December 2012), 1051-1079.

Eeckhout, Jan, “On the Uniqueness of Stable Marriage Matchings,” Economic Letters, Vol. 69, No. 1, (October 2000), 1-8.

Edin, Kathryn and Maria Kefalas, Promises I Can Keep: Why Poor Women Put Motherhood Before Marriage, Berkeley, University of California Press, 2005.

Edin, Kathryn and Timothy J. Nelson, Doing the Best I Can: Fatherhood in the City, Berkeley: University of California Press, 2013.

Ellickson, Robert C., "Unpacking the Household: Informal Property Rights Around the Hearth," Yale Law Journal, Vol. 116, No. 2, (November 2006), 226-328.

Ellickson, Robert C., The Household: Informal Order around the Hearth, Princeton: Princeton University Press, 2008.

Farrell, Joseph, "Information and the Coase Theorem," Journal of Economic Perspectives, Vol. 1, No. 2, (Fall 1987), 113-129.

Furstenberg, Frank, Jr. "The Fading Dream: Prospects for Marriage in the Inner City." In Problem of the Century: Racial Stratification in the United States, ed. by Elijah Anderson and Douglas S. Massey, New York: Russell Sage, 2001, 224-246.

Gale, David and Lloyd Shapley, "College Admissions and the Stability of Marriage," American Mathematical Monthly, Vol. 69, No. 1, (January 1962), 9-15.

Gibson-Davis, Christina M., Kathryn Edin, and Sara McLanahan, "High Hopes but Even Higher Expectations: The Retreat from Marriage Among Low-Income Couples," Journal of Marriage and Family, Vol. 67, No. 5, (December 2005): 1301-1312. 
Goldscheider, Frances, Eva Bernhardt, and Trude Lappegård, "The Gender Revolution:

Understanding Changing Family and Demographic Behavior," Population and Development

Review, Vol. 41, No. 2, (June 2015), 207-240.

Hajnal, John, "European Marriage Pattern in Historical Perspective," in D. V. Glass and D. E. C. Eversley, eds., Population in History, London: Edward Arnold, 1965.

Hartog, Hendrik, Man and Wife in America: A History, Cambridge: Harvard University Press, 2000 .

Hasday, Jill Elaine, Family Law Reimagined. Cambridge: Harvard University Press, June 2014.

Hatfield, John William and Paul R. Milgrom, "Matching with Contracts," American Economic Review, Vol. 95, No. 4, (September 2005), 913-935.

Kennedy, Sheela and Steven Ruggles, "Breaking Up Is Hard to Count: The Rise of Divorce in the United States, 1980-2010," Demography, Vol. 51, No. 2, (April 2014), 587-598.

Klüsener, Sebastian, Brienna Perelli-Harris, and Nora Sánchez Gassen, "Spatial Aspects of the Rise of Non-marital Fertility Across Europe Since 1960: The Role of States and Regions in Shaping Patterns of Change," European Journal of Population, Vol. 29, No. 2, (May 2013), 137165.

Konrad, Kai A. and Kjell Erik Lommerud, "Love and Taxes -- and Matching Institutions," Canadian Journal of Economics, Vol. 43, No. 3, (August 2010), 919-940.

Koopmans, Tjalling C., and Martin Beckmann, "Assignment Problems and the Location of Economic Activities,” Econometrica, Vol. 25, No. 1, (January 1957), 53-76.

Laferrère, Anne, "Marriage Settlements," The Scandinavian Journal of Economics, Vol. 103, No. 3, (September 2001), 485-504.

Lam, David, "Marriage Markets and Assortative Mating with Household Public Goods: Theoretical Results and Empirical Implications," Journal of Human Resources, Vol. 23, No. 4 (fall 1988), 462487.

Lee, James Z. and Wang Feng, One Quarter of Humanity: Malthusian Mythology and Chinese Realities, Cambridge: Harvard University Press, 1999.

Levmore, Saul, "Love it or Leave It: Property Rules, Liability Rules, and Exclusivity of Remedies in Partnership and Marriage," Law and Contemporary Problems, Vol. 58, No. 2, (Spring 1995), 221-249.

Lundberg, Shelly and Robert A. Pollak, "Separate Spheres Bargaining and the Marriage Market," Journal of Political Economy, Vol. 101, No. 6, (December 1993), 988-1010.

Lundberg, Shelly and Robert A. Pollak, "Efficiency in Marriage," Review of Economics of the Household, Vol. 1, No. 3, (September 2003), 153-168. 
Lundberg, Shelly and Robert A. Pollak, "Family Decision-Making," in The New Palgrave Dictionary of Economics, 2nd Edition, Larry Blume and Steven Durlauf, eds. Palgrave Macmillan. 2008.

Lundberg, Shelly and Robert A. Pollak, "Cohabitation and the Uneven Retreat from Marriage in the U.S., 1950-2010," in Leah P. Boustan, Carola Frydman, and Robert A. Margo, eds. Human Capital and History: The American Record, Chicago: University of Chicago Press, 2014, 241-272.

Lundberg, Shelly and Robert A. Pollak, "The Evolving Role of Marriage: 1950 - 2010," Future of Children, Vol. 25, No. 2, (Fall 2015), 29-50.

Lundberg, Shelly, Robert A. Pollak, and Jenna Stearns, "Family Inequality: Diverging Patterns in Marriage, Cohabitation, and Childbearing," forthcoming, Journal of Economic Perspectives, 2016.

Lundberg, Shelly, Robert A. Pollak, and Terence J. Wales, "Do Husbands and Wives Pool Their Resources? Evidence from the U.K. Child Benefit," Journal of Human Resources, Vol. 32, No. 3, (Summer 1997), 463-480.

Manser, Marilyn and Murray Brown, "Marriage and Household Decision-Making: A Bargaining Analysis," International Economic Review, Vol. 21, No. 1, (February 1980), 31-44.

Marston, Allison A., "Planning for Love: The Politics of Prenuptial Agreements," Stanford Law Review, Vol. 49, No. 4, (April 1997), 887-916.

McElroy, Marjorie B., "The Policy Implication of Family Bargaining and Marriage Markets." In Intrahousehold Resource Allocation in Developing Countries: Models, Methods, and Policy, ed. by Lawrence Haddad, John Hoddinott, and Harold Alderman. Baltimore: Johns Hopkins University Press, 1997, 53-74.

McElroy, Marjorie B. and Mary J. Horney, "Nash-Bargained Household Decisions: Toward a Generalization of the Theory of Demand," International Economic Review, Vol. 22, No. 2, (June 1981), 333-349.

Perelli-Harris, Brienna, Wendy Sigle-Rushton, Trude Lappegard, Renske Keizer, Michaela Kreyenfeld, and Caroline Berghammer, "The Educational Gradient of Childbearing Within Cohabitation in Europe," Population and Development Review, Vol. 36, No. 4, (December 2010), 775-801.

Pollak, Robert A., “A Transaction Cost Approach to Families and Households,” Journal of Economic Literature, Vol. 23, No. 2 (June 1985), 581-608.

Pollak, Robert A., "Legal Enforceability and Bargaining Models of Marriage: Comment on Mary Anne Case's 'Enforcing Bargains in an Ongoing Marriage"' Washington University Journal of Law and Policy, Vol. 35 (2011), 261-272.

Rosenbury, Laura A., "Two Ways to End a Marriage: Divorce or Death," Utah Law Review, 2005, 1227-1290.

Roth, Alvin E. and Marilda A. Oliveira Sotomayor, Two-sided Matching: A Study in GameTheoretic Modeling and Analysis, Cambridge: Cambridge University Press, 1990. 
Schultz, T. Paul, "Testing the Neoclassical Model of Family Labor Supply and Fertility," Journal of Human Resources, Vol. 25, No. 4, (Fall 1990), 599-634.

Sevilla-Sanz, Almudena, "Social Effects, Household Time Allocation, and the Decline in Union Formation," Congressional Budget Office, 2005-7, May 2005.

Sevilla-Sanz, Almudena, "Household Division of Labor and Cross-Country Differences in Household Formation Rates," Journal of Population Economics, Vol. 23, No. 1, (January 2010), 225-249.

Shapley, Lloyd S. and Martin Shubik, "The Assignment Game 1: The Core," International Journal of Game Theory, Vol. 1, No. 1, (December 1971), 111-130.

Sigler, Emy, "Elgar v. Probate Appeal: The Probate Court's Implied Powers to Construe and to Enforce Pre-Nuptial Agreements," Connecticut Probate Law Journal, Vol. 9, (1994), 145-160.

Smith, Lones , "The Marriage Model with Search Frictions," Journal of Political Economy, Vol. 114, No. 6, (December 2006), 1124-1146.

Siow, Aloysius, "Testing Becker's Theory of Positive Assortative Matching," Journal of Labor Economics, Vol 33, No. 2, (April 2015), 409-441.

Stark, Ellen, "A Quickie Guide to Prenups for Trump, Gates -- and You," Money, Vol. 22, No. 6, (June 1993), 17.

Stevenson, Betsey, and Justin Wolfers, "Marriage and Divorce: Changes and their Driving Forces," Journal of Economic Perspectives, Vol. 21, No. 2, (Spring 2007), 27-52.

Stone, Lawrence, Road to Divorce: England 1530-1987, Oxford: Oxford University Press, 1990.

Thaler, Richard H. and Cass R. Sunstein, Nudge: Improving Decisions About Health, Wealth, and Happiness, Yale University Press, 2008.

Thomas, Duncan, "Intra-Household Resource Allocation: An Inferential Approach," Journal of Human Resources, Vol. 25, No.4, (Fall 1990), 635-664.

Ward-Batts, Jennifer, "Out of the Wallet and into the Purse: Modeling Family Expenditures to Test Income Pooling," Journal of Human Resources, Vol. 43, No. 2, (Spring 2008), 325-351.

Wrigley, E. A., "European Marriage Patterns and Their Implications: John Hajnal's Essay and Historical Demography During the Last Half-Century," in Chris Briggs, P.M. Kitson, and S.J. Thompson, eds., Population, Welfare and Economic Change in Britain 1290-1834. People, Markets, Goods: Economies and Societies in History, Volume 5. Woodbridge: The Boydell Press, 2014. 15-41. 